\title{
PENGARUH PEMBERIAN EKSTRAK DAUN SALAM (Syzygium polyanthum Wight.) TERHADAP GLIBENKLAMID DALAM MENURUNKAN KADAR GLUKOSA DARAH MENCIT(Mus musculus) YANG DIINDUKSI ALOKSAN
}

\section{THE IMPACT OF ADMINISTRATION BAY LEAF EXTRACT (Syzygium polyanthum Wight.) ON GLIBENCLAMIDE IN LOWERING BLOOD GLUCOSE LEVELS ON MICE(Mus musculus)THAT INDUCED BY ALLOXAN}

\author{
Nur Hikmah $^{1}{ }^{*}$, Yuliet $^{1}$, Khildah Khaerati ${ }^{1}$ \\ ${ }^{1}$ Jurusan Farmasi, Fakultas MIPA,UniversitasTadulako, Palu, Indonesia
}

Received 4 Desember 2015, Accepted 10 Februari 2016

\begin{abstract}
ABSTRAK
Penggunaan obat herbal dan obat sintetik secara bersamaan banyak dilakukan oleh penderita diabetes untuk pemeliharaan kadar glukosa darah yang lebih baik, seperti penggunaan glibenklamid dan daun salam. Penelitian ini bertujuan untuk melihat pengaruh pemberian ekstrak daun salam terhadap glibenklamid dalam menurunkan kadar glukosa darah mencit yang diinduksi aloksan. Penelitian ini menggunakan 40 ekor mencit putih jantan yang terbagi dalam 8 kelompok. Sebelum diberi perlakuan, hewan uji dibuat diabetes dengan induksi aloksan $(70 \mathrm{mg} / \mathrm{kg}$ BB$)$ terlebih dahulu secara intravena. Kelompok kontrol negatif merupakan kelompok yang diberikan Na CMC 0,5\%, KG merupakan kontrol glibenklamid 0,65 mg/kg BB, kelompok DS1, DS2, DS3 adalah kelompok kontrol ekstrak daun salam tunggal dengan dosis masing-masing $250 \mathrm{mg} / \mathrm{kg}$ $\mathrm{BB}, 500 \mathrm{mg} / \mathrm{kg} \mathrm{BB}$, dan $750 \mathrm{mg} / \mathrm{kg} \mathrm{BB}$, kelompok KD1, KD2, KD3 adalah kelompok kombinasi glibenklamid dan ekstrak daun salam dengan dosis masing-masing glibenklamid dikombinasikan dengan ekstrak daun salam $250 \mathrm{mg} / \mathrm{kg} \mathrm{BB}$, glibenklamid dikombinasikan dengan ekstrak daun salam $500 \mathrm{mg} / \mathrm{kg} \mathrm{BB}$, dan glibenklamid dikombinasikan dengan ekstrak daun salam750 mg/kg BB, dengan selang waktu pemberian 1 jam. Data yang diperoleh dianalisis secara statistik dengan menggunakan ANOVA (analysis of variance) pada taraf kepercayaan 95\% dengan parameter selisih penurunan kadar glukosa darah. Hasil penelitian menunjukkan bahwa pemberian ekstrak daun salam berpengaruh secara signifikan terhadap glibenklamid dalam menurunkan kadar glukosa darah dan dosis yang efektif adalah kombinasi dosis glibenklamid 0,65 mg/kg BB dan ekstrak daun salam $250 \mathrm{mg} / \mathrm{kg}$ BB.
\end{abstract}

Kata kunci: Aloksan, Syzygium polyanthum Wight., Glibenklamid.

\section{ABSTRACT}

The use of herbal medicines and synthetic drugssimultaneously carried out by diabetics for the maintenance of blood glucose levels, such as the use of glibenclamide and bay leaf. This research was carried out to know the impact of administration bay leaf extract on glibenclamide in lowering blood glucose levels on mices that induced by alloxan. This research used 40 male mices which were divided into 8 groups. Before the experiment, the mices were first induced by alloxan $(70 \mathrm{mg} / \mathrm{kg} \mathrm{BW})$ intravenously. The negative control was the group that given $\mathrm{Na}$ CMC $0,5 \%, \mathrm{KG}$ was the control of glibenclamide $0,65 \mathrm{mg} / \mathrm{kg} \mathrm{BW}$, group DS1, DS2, DS3 were the control of single bay leaf extract with each dose $250 \mathrm{mg} / \mathrm{kg} \mathrm{BW}, 500 \mathrm{mg} / \mathrm{kg} \mathrm{BW}$, and $750 \mathrm{mg} / \mathrm{kg}$ $\mathrm{BW}$, group $\mathrm{KD} 1, \mathrm{KD} 2, \mathrm{KD} 3$ were the combination group of glibenclamide and bay leaf extract with each dose glibenclamide combined bay leaf extract $250 \mathrm{mg} / \mathrm{kg} \mathrm{BW}$, glibenclamide combined bay leaf extract $500 \mathrm{mg} / \mathrm{kg}$ $\mathrm{BW}$, and glibenclamide combined bay leaf extract $750 \mathrm{mg} / \mathrm{kg} \mathrm{BW}$, with an hour interval. The data were statistically analyzed using ANOVA (Analysis of Variance) at 95\% confidence interval with parameter of blood glucose levels difference between before and after treatment.The results showed that the administration of bay leaf extract gave significant impact on glibenclamide in lowering blood glucose levels and the effective dose was the combination of glibenclamide $0,65 \mathrm{mg} / \mathrm{kg}$ BWand bay leaf extract $250 \mathrm{mg} / \mathrm{kg} \mathrm{BW}$.

Keywords:Alloxan, Syzygium polyanthum Wight, Glibenclamide.

*Correspondence author : Nurhikmah, Hikmahn86@gmail.com(ph : +62-852-411-808-67) 


\section{PENDAHULUAN}

International Diabetes Federation

(IDF) Diabetes Atlas menunjukkan bahwa $8,3 \%$ dari orang dewasa (382 juta orang) menderita diabetes, dan jumlah penderita ini akan meningkat melampaui 592 juta dalam waktu kurang dari 25 tahun.

Daun salam (Syzygium polyanthum Wight.) merupakan salah satu obat herbal antidiabetes yang banyak dikonsumsi masyarakat. Penelitian sebelumnya membuktikan bahwa ekstrak etanol daun salam dapat menurunkan kadar glukosa darah mencit yang diinduksi aloksan pada dosis $2,64 \mathrm{mg} / 20 \mathrm{~g}$ BB $(26,6 \%)$ dan $5,24 \mathrm{mg} / 20 \mathrm{~g}$ BB (34,2\%) (Studiawan \& Santosa, 2005). Selain itu, penelitian sebelumnya juga menunjukkan bahwa ekstrak etanol daun salam pada dosis $249,6 \mathrm{mg} / \mathrm{kg}$ BB dan 499,2 $\mathrm{mg} / \mathrm{kg}$ BB dapat menurunkan kadar glukosa darah mencit yang diinduksi aloksan sebanding dengan glibenklamid (Carolina, R., 2007).

Kombinasi antara obat herbal dan obat sintesis tidak menutup kemungkinan terjadinya interaksi. Ada kekhawatiran munculnya efek hipoglikemik yang berlebihan apabila antidiabetes herbal dikonsumsi bersama dengan ADO. Hasil penelitian Steffi Liem, 2015 menunjukkan bahwa kombinasi ekstrak daun salam dan glibenklamid dapat menurunkan kadar glukosa darah yang signifikan pada mencit yang diinduksi aloksan dibandingkan dengan pemberian tunggal glibenklamid ataupun ekstrak daun salam.

Berdasarkan uraian diatas, peneliti ingin mengetahui pengaruh pemberian ekstrak daun salam terhadap glibenklamid dalam menurunkan kadar glukosa darah. Sebagai model diabetes, digunakan mencit yang mengalami keadaan hiperglikemia akibat induksi senyawa aloksan.

\section{METODE PENELITIAN Jenis Penelitian}

Penelitian yang dilakukan merupakan eksperimen laboratorium dengan rancangan acak lengkap pola searah. Kelompok perlakuan dibagi menjadi 8 kelompok uji, masing-masing terdiri dari 5 ekor mencit. Kemudian dilakukan pengukuran kadar glukosa darah mencit sebelum dan setelah diinduksi dengan aloksan untuk membuat model hewan diabetes. Lalu diberikan perlakuan sesuai kelompok uji.

\section{Lokasi dan Waktu Penelitian}

Penelitian dilaksanakan di

Laboratorium Farmakognosi-Fitokimia dan Farmakologi-Biofarmasi Jurusan Farmasi, FMIPA, Universitas Tadulako selama 9 bulan, yakni dari bulan Februari 2015 sampai November 2015.

\section{Persiapan Bahan Uji}

Bahan uji yang digunakan adalah daun salam (Syzygium polyanthum Wight.)yang diperoleh dari Desa Lolu KecamatanBiromaru Kabupaten Sigi dan dilakukan identifikasi di Unit Pelaksana Teknis (UPT) Sumber Daya Hayati Sulawesi Universitas Tadulako Palu.Daun salam dibersihkan dengan air dan ditiriskan, lalu dirajang berukuran kecil, kemudian dikeringkan dengan cara diangin-anginkan dan selanjutnya diserbukkan hingga halus. Serbuk daun salamsebanyak 500 gram dimaserasi dengan menggunakan etanol $96 \%$ sebanyak 2,5 L. Setelah itu disaring untuk mendapatkan maserat. Lalu maserat yang diperoleh dievaporasidengan rotary evaporator kemudian diuapkan di atas waterbath hingga didapatkan ekstrak kental dan ditimbang untuk menghitung rendemennya.

\section{Uji Penapisan Fitokimia (Harborne, 1987)}

Ekstrak daun salam yang telah didapatkan kemudian diuji kualitatif terhadap adanya senyawa flavonoid, fenolik, saponin, steroid, triterpenoid, alkaloid, dan tanin di Laboratorium Farmakognosi-Fitokimia Jurusan Farmasi Fakultas MIPA Universitas Tadulako.

\section{Pengujian Aktivitas Antidiabetes}

Hewan uji yang digunakan berjumlah 40 ekor, kemudian dibagi menjadi 8 kelompok uji, dengan masing-masing kelompok berjumlah 5 ekor. Hewan uji dipuasakan selama 16 jam dengan tetap diberi minum, kemudian darah diambil melalui vena ekor mencit dan diukur kadar glukosa darahnya sebagai kadar glukosa darah puasa awal $\left(\mathrm{H}_{1}\right)$, kemudian semua hewan uji dibuat diabetes dengan induksi aloksan $70 \mathrm{mg} / \mathrm{kg}$ BB. Pada hari ke-8 kadar glukosa darah puasa hewan uji diukur kembali untuk melihat efek 
hiperglikemia yang terjadi. Setelah mengalami hiperglikemia, masing-masing hewan uji diberi perlakuan sesuai kelompok uji. Untuk kelompok KD1, KD2, dan KD3 pemberian pertama adalah suspensi glibenklamid dosis $0,65 \mathrm{mg} / \mathrm{kg}$ BB lalu satu jam kemudian diberi ekstrak daun salam dengan dosis masing-masing $250 \mathrm{mg} / \mathrm{kg} \mathrm{BB}$, $500 \mathrm{mg} / \mathrm{kg}$ BB dan $750 \mathrm{mg} / \mathrm{kg}$ BB.

Pemberian seluruh bahan uji dilakukan setiap hari selama dua minggu. Pengukuran kadar glukosa darah dilakukan pada hari ke15 dan hari ke-22. Mencit dianggap sudah mengalami hiperglikemia apabila kadar glukosa darah puasa $>200 \mathrm{mg} / \mathrm{dL}$ (AlarconAguilara et al., 1998).

\section{Analisis Data}

Data penurunan kadar glukosa darah yang diperoleh dianalisis secara statistik dengan menggunakan One Way Anova. Data yang diperoleh sebelumnya diuji normalitasnya dengan uji Saphiro Wilk. Data dikatakan terdistribusi normal jika $\mathrm{p}>0,05$. Kemudian dilanjutkan dengan uji homogenitas (uji Levene), jika nilai p > 0,05 berarti data yang didapatkan homogen. Selanjutnya dilakukan uji statistik One Way Anova pada taraf kepercayaan 95\%. Apabila ada perbedaan antar kelompok dilanjutkan dengan uji analisis Post Hoc Duncan untuk mengetahui kelompok perlakuan yang memiliki perbedaan signifikan.

\section{HASIL DAN PEMBAHASAN Hasil}

Hasil rendemen yang diperoleh dari proses ekstraksi sebesar10,62\%. Berdasarkan penapisan fitokimia yang telah dilakukan diperoleh hasil bahwa ekstrak daun salam positif mengandung senyawa flavonoid, fenolik, saponin, triterpenoid, alkaloid dantanin. Senyawa-senyawa inilah yang berperan dalam memberikan khasiat dan efek biologis.

Pengamatan terhadap kadar glukosa darah mencit dilakukan sebelum induksi, setelah hiperglikemia dan selama 14 hari pemberian perlakuan. Pada hari ke-1, hari ke8 setelah induksi aloksan, hari ke-15, dan hari ke-22 dilakukan pengukuran kadar glukosa darah dalam setiap kelompok uji yang sebelumnya telah dipuasakan. Berikut adalah hasil pengukuran dan grafik profil kadar glukosa darah puasa rata-rata setiap kelompok uji.

Tabel 1. Hasil Pengukuran Rerata Kadar Glukosa Darah Mencit

\begin{tabular}{ccccc}
\hline \multirow{2}{*}{$\begin{array}{c}\text { Kelompok } \\
\text { Perlakuan }\end{array}$} & \multicolumn{4}{c}{ Kadar Glukosa Darah } \\
& (rerata \pm SD) mg/dL \\
\cline { 2 - 5 } Kontrol - & $\mathrm{H}_{1}$ & $\mathrm{H}_{8}$ & $\mathrm{H}_{15}$ & $\mathrm{H}_{22}$ \\
& \pm & 350,8 & 424,2 & 429,6 \\
& 13,03 & \pm & \pm & \pm \\
KG & $83 \pm$ & 27,08 & 44,85 & 67,18 \\
& 6,08 & \pm & 127,4 & $98 \pm$ \\
& 97,6 & 253,4 & 175,6 & 118 \\
DS1 & \pm & \pm & \pm & \pm \\
& 16,94 & 30,41 & 26,20 & 15,76 \\
& 90,8 & 297,8 & 195,2 & 134,6 \\
DS2 & \pm & \pm & \pm & \pm \\
& 17,72 & 51,24 & 40,26 & 5,72 \\
& 117,6 & 314,6 & 177 & 124,4 \\
DS3 & \pm & \pm & \pm & \pm \\
& 30,43 & 68,74 & 46,24 & 26,83 \\
& 103 & & 149,2 & 117,6 \\
KD1 & \pm & $355 \pm$ & \pm & \pm \\
& 9,27 & 106,07 & 60,68 & 31,91 \\
& 93,4 & 329,6 & 113,4 & 83,6 \\
KD2 & \pm & \pm & \pm & \pm \\
& 15,85 & 21,27 & 8,61 & 4,61 \\
& 93,2 & 393,2 & 161 & 105,8 \\
KD3 & \pm & \pm & \pm & \pm \\
& 20,54 & 69,82 & 45,02 & 65,05 \\
\hline & & & &
\end{tabular}

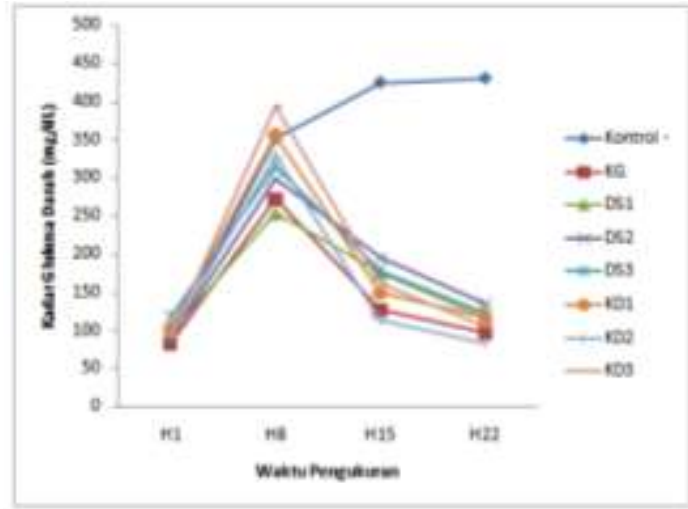

Gambar 1. Profil rerata kadar glukosa darah mencit

Keterangan :

$\mathrm{H}_{1}$ : kadar glukosa darah awal sebelum pemberian sediaan uji

$\mathrm{H}_{8}$ : kadar glukosa darah setelah pemberian aloksan $70 \mathrm{mg} / \mathrm{kg}$ BB

$\mathrm{H}_{15}$ : kadar glukosa darah setelah 7 hari pemberian sediaan uji 
$\mathrm{H}_{22}$ : kadar glukosa darah setelah 14 hari pemberian sediaan uji

Kontrol -: kelompok perlakuan yang diberikan $\mathrm{Na}$ CMC 0,5\%

$\mathrm{KG}$ : kelompok perlakuan yang diberikan glibenklamid $0,65 \mathrm{mg} / \mathrm{kg} \mathrm{BB}$

DS1: kelompok ekstrak daunsalam 250 $\mathrm{mg} / \mathrm{kg} \mathrm{BB}$

DS2: kelompok ekstrak daun salam 500 $\mathrm{mg} / \mathrm{kg} \mathrm{BB}$

DS3: kelompok ekstrak daun salam 750 $\mathrm{mg} / \mathrm{kg} \mathrm{BB}$

KD1: kelompok kombinasi glibenklamid $0,65 \mathrm{mg} / \mathrm{kg} \mathrm{BB}+$ ekstrak daun salam $250 \mathrm{mg} / \mathrm{kg} \mathrm{BB}$

KD2: kelompok kombinasi glibenklamid $0,65 \mathrm{mg} / \mathrm{kg} \mathrm{BB}+$ ekstrak daun salam $500 \mathrm{mg} / \mathrm{kg} \mathrm{BB}$

KD3: kelompok kombinasi glibenklamid $0,65 \mathrm{mg} / \mathrm{kg} \mathrm{BB}+$ ekstrak daun salam $750 \mathrm{mg} / \mathrm{kg} \mathrm{BB}$

Tabel2. Selisih penurunan rerata kadar glukosa darah

\begin{tabular}{|c|c|c|}
\hline \multirow[t]{2}{*}{$\begin{array}{l}\text { Kelompok } \\
\text { Perlakuan }\end{array}$} & \multicolumn{2}{|c|}{$\begin{array}{c}\text { Selisih Penurunan Rerata Kadar Glukosa } \\
\text { Darah (rerata } \pm \text { SD) } \mathrm{mg} / \mathrm{dL}\end{array}$} \\
\hline & $\Delta_{1}$ & $\Delta_{2}$ \\
\hline Kontrol - & $-73,4 \pm 143,02$ & $-78,8 \pm 115,12$ \\
\hline KG & $144,2 \pm 46,05^{\mathrm{b}}$ & $173,6 \pm 60,55^{\mathrm{ab}}$ \\
\hline DS1 & $77,8 \pm 24,80^{\mathrm{a}}$ & $135,4 \pm 28,89^{a}$ \\
\hline DS2 & $102,6 \pm 14,87^{\mathrm{ab}}$ & $163,2 \pm 47,99^{\mathrm{a}}$ \\
\hline DS3 & $137,6 \pm 26,42^{b}$ & $190,2 \pm 46,98^{\mathrm{ab}}$ \\
\hline KD1 & $205,8 \pm 51,57^{\mathrm{c}}$ & $237,4 \pm 75,11^{\mathrm{bc}}$ \\
\hline KD2 & $216,2 \pm 21,25^{\mathrm{c}}$ & $246 \pm 23,09^{b c}$ \\
\hline KD3 & $232,2 \pm 33,00^{\mathrm{c}}$ & $287,4 \pm 65,05^{\mathrm{c}}$ \\
\hline
\end{tabular}

Keterangan:

$\Delta 1$ : Selisih penurunan kadar glukosa darah $\mathrm{H}_{8}$ dan $\mathrm{H}_{15}$

$\Delta 2$ : Selisih penurunan kadar glukosa darah $\mathrm{H}_{8}$ dan $\mathrm{H}_{22}$

Kontrol -: kelompok perlakuan yang diberikan Na CMC 0,5\%

KG : kelompok perlakuan yang diberikan glibenklamid $0,65 \mathrm{mg} / \mathrm{kg} \mathrm{BB}$

DS1: kelompok ekstrak daun salam 250 $\mathrm{mg} / \mathrm{kg} \mathrm{BB}$

DS2: kelompok ekstrak daun salam 500 $\mathrm{mg} / \mathrm{kg} \mathrm{BB}$

DS3: kelompok ekstrak daun salam 750 $\mathrm{mg} / \mathrm{kg} \mathrm{BB}$

KD1: kelompok kombinasi glibenklamid $0,65 \mathrm{mg} / \mathrm{kg} \mathrm{BB}+\mathrm{ekstrak}$ daun salam $250 \mathrm{mg} / \mathrm{kg} \mathrm{BB}$

KD2: kelompok kombinasi glibenklamid $0,65 \mathrm{mg} / \mathrm{kg} \mathrm{BB}+$ ekstrak daun salam $500 \mathrm{mg} / \mathrm{kg} \mathrm{BB}$
KD3: kelompok kombinasi glibenklamid $0,65 \mathrm{mg} / \mathrm{kg} \mathrm{BB}+$ ekstrak daun salam $750 \mathrm{mg} / \mathrm{kg} \mathrm{BB}$

- Abjad yang sama menunjukkan tidak ada perbedaan yang bermakna.

- Abjad yang berbeda menunjukkan perbedaan yang bermakna.

\section{Pembahasan}

Penelitian ini menggunakan ekstrak daun salam (SyzygiumpolyanthumWight.) yang telah dilakukan identifikasi untuk memastikan bahwa benar tanaman yang digunakan adalah daun salam (SyzygiumpolyanthumWight.). Ekstrak daun salam diperoleh dari proses maserasi menggunakan pelarut etanol 96\%. Ekstrak kental yang didapatkan sebanyak 53,14 gram dengan rendemen yang diperoleh sebesar $10,62 \%$.

Penelitian ini menggunakan mencit jantan sebagai hewan uji. Mencit jantan dipilih karena mencit jantan mempunyai kecepatan metabolisme obat yang lebih cepat dengan kondisi biologis yang lebih stabil dibanding mencit betina. Mencit jantan pada usia 2-3 bulan adalah mencit dewasa muda yang mempunyai keadaan fisiologik yang optimum. Mencit yang digunakan terlebih dahulu diadaptasi selama 7 hari agar dapat menyesuaikan diri dengan lingkunganya selama penelitian berlangsung.

Hewan uji diukur kadar glukosa darah awal dan hasil pengukuran menunjukkan bahwa kadar glukosa darah masing-masing mencit berkisar antara $83 \pm 6,08-117,6 \pm 30,43$ $\mathrm{mg} / \mathrm{dL}$. Hal ini menunjukkan bahwa seluruh hewan uji memiliki kadar glukosa darah normal, yakni berkisar antara $62-175 \mathrm{mg} / \mathrm{dL}$ (Malole \& Pramono, 1989).Selanjutnya dilakukan penginduksian dengan memberikan aloksan dosis $70 \mathrm{mg} / \mathrm{kg}$ BB secara intravena untuk membuat hewan uji diabetes. Pemilihan aloksan sebagai agen penginduksi diabetes dikarenakan kemampuannya untuk membuat hewan uji terkondisi sama seperti pasien DM. Selain itu, aloksan dapat menimbulkan keadaan hiperglikemia permanen dalam waktu yang cukup singkat yaitu 2-3 hari setelah induksi (Anonim, 1993).

Pengukuran kadar glukosa darah puasa dilakukan kembali pada hari ke-8 untuk memastikan bahwa mencit mengalami hiperglikemia. Penginduksian aloksan akan 
menyebabkan kadar glukosa darah mengalami fluktuasi selama 24-36 jam yang meliputi fase hiperglikemia dan hipoglikemia yang terjadi secara bergantian sebelum terjadinya hiperglikemia permanen.

Hasil pengukuran kadar glukosa darah hari ke-8 memperlihatkan terjadinya peningkatan kadar glukosa darah. Data peningkatan kadar glukosa darah yang diperoleh cukup beragam. Hal ini disebabkan karena respon tubuh tiap mencit terhadap aloksan berbeda sehingga menghasilkan peningkatan kadar glukosa darah yang berbeda pula. Peningkatan kadar glukosa darah oleh aloksan disebabkan antara lain kerusakan pada pada sel beta pankreas karena pembentukan oksigen reaktif dan gangguan homeostasis kalsium intraseluler(Lenzen \&Panten, 1988). Kadar glukosa darah mencit mengalami kenaikan berkisar antara 253,4 \pm $30,41-393,2 \pm 69,82 \mathrm{mg} / \mathrm{dL}$.

Mencit yang hiperglikemia mengalami poliuria. Hal ini terlihat pada kondisi kandang yang lembab. Mencit ini kemudian diberi perlakuan sesuai kelompok uji secara oral selama 14 hari. Kontrol positif glibenklamid digunakan sebagai pembanding untuk melihat pengaruh antidiabetika oral yang telah terbukti khasiatnya untuk menurunkan kadar glukosa darah. Glibenklamid merupakan obat golongan sulfonilurea generasi kedua, yang sering digunakan pada pasien DM. Glibenklamid tidak larut dalam air sehingga disuspensikan dengan zat pensuspensi $\mathrm{Na}$ CMC 0,5\%.Glibenklamid tidak larut dalam air sehingga diberikan dalam bentuk suspensi menggunakan agen pensuspensi Na CMC. Alasan pemilihan $\mathrm{Na}$ CMC dikarenakan sistem pencernaan mencit tidak memiliki enzim selulase, maka penggunaan $\mathrm{Na} \mathrm{CMC}$ tidak akan berpengaruh pada kadar glukosa darah (Akhtar, M. S., dkk., 1981). Dosis glibenklamid yang digunakan adalah 0,65 $\mathrm{mg} / \mathrm{kg}$ BB. Dosis tersebut digunakan berdasarkan dosis efektif oral pada manusia yaitu $5 \mathrm{mg} /$ hari yang kemudian dikonversi ke dosis mencit. Ekstrak daun salam tunggal juga digunakan sebagai faktor koreksi, untuk melihat efek sinergis atau antagonis yang dihasilkan oleh kombinasi glibenklamid dan ekstrak daun salam terhadap penurunan kadar glukosa darah. Kontrol negatif yakni kontrol yang diinduksi aloksan sehingga menyebabkan diabetes diperlukan untuk mengetahui penurunan kadar glukosa darah dari keadaan normal selama penelitian. Pengukuran kadar glukosa darah dilakukan pada hari ke-15 dan hari ke-22.

Hasil pengukuran kadar glukosa darah kelompok kontrol positif dan kontrol uji pada hari ke-15 dan ke-22 menunjukkan adanya penurunan kadar glukosa darah secara bertahap.Sedangkan kelompok kontrol negatif $\mathrm{Na} \mathrm{CMC}$ 0,5\% masih mengalami hiperglikemia.Berdasarkan hal tersebut maka untuk kontrol negatif $\mathrm{Na}$ CMC $0,5 \%$ tidak dilakukan uji statistik. Penurunan kadar glukosa darah juga ditandai dengan penurunan gejala poliuria.

Hasil uji statistik selisih penurunan kadar glukosa darah pada hari ke-15 menunjukkan adanya perbedaan bermakna antara kelompok KD1, KD2, KD3 dengan kelompok kontrol glibenklamid maupun kelompok DS1, DS2, DS3. Sedangkan hasil uji statistik kelompok DS2 menunjukkan perbedaan tidak bermakna dengan kelompok DS1, DS3, dan kontrol glibenklamid. Hal ini terjadi karena penurunan kadar glukosa darah kelompok KD1, KD2, KD3 jauh lebih besar dibandingkan kelompok kontrol glibenklamid maupun ekstrak daun salam tunggal, dimana kadar glukosa rata-rata kelompok KD1, KD2, KD3 sudah mencapai kadar glukosa darah normal sedangkan kadar glukosa rata-rata kelompok DS1, DS2, DS3 masih tetap tinggi. Kejadian ini memperlihatkan terjadinya interaksi sinergis, dimana efek antihiperglikemik yang dihasilkan oleh kelompok kombinasi lebih besar dibandingkan kelompok tunggal masingmasing.

Hal yang sama juga terjadi pada hari ke-22. Penurunan kadar glukosa darah kelompok KD1, KD2, KD3 jauh lebih besar dibandingkan kelompok kontrol glibenklamid dan kelompok ekstrak daun salam tunggal. Penurunan kadar glukosa darah tertinggi pada hari ke-22 adalah kelompok kombinasi glibenklamid dan ekstrak daun salam 750 $\mathrm{mg} / \mathrm{kg} \mathrm{BB}$, yaitu 287,4 $\pm 65,05$.

Peningkatan efek terjadi berbarengan dengan peningkatan dosis daun salam yang diberikan dalam penggunaan kombinasi. Semakin tinggi dosis yang digunakan, maka semakin besar pula efek penurunan kadar glukosa darah yang dihasilkan. Namun, hasil uji statistik ANOVA menunjukkan bahwa kelompok KD1, KD2, dan KD3tidak memberikan perbedaan yang bermakna, 
sehingga kombinasi dosis yang efektif adalah KD1, yakni kombinasi glibenklamid dan ekstrak daun salam $250 \mathrm{mg} / \mathrm{kg}$ BB.

Analisis fitokimia yang diperoleh menunjukkan bahwa pada ekstrak daun salam memberikan hasil positif terhadap golongan senyawa flavonoid, fenolik, saponin, terpenoid, alkaloid dan tanin. Senyawasenyawa inilah yang berperan sebagai antidiabetes.

Flavonoid diketahui mampu menangkap radikal bebas (ROS/Reactive Oxygen Species atau RNS/Reactive Nitrogen Species) melalui transfer elektron, serta menghambat reaksi peroksidasi (Lugasi, Hovari, Sagi, \& Biro, 2003). Flavonoid merupakan pengkhelat logam dan menghambat reaksi Fenton dan HaberWeiss, yang penting sebagai sumber radikal oksigen reaktif (Shahidi \& Wanasundara, 1992). Flavonoid dapat bekerja secara langsung terhadap sel beta pankreas, dengan memicu pengaktifan kaskade sinyal cAMP dalam memperkuat sekresi insulin yang disensitisasi oleh glukosa (Brahmachari, 2011).

Senyawa fenolik di dalam daun salam seperti 3,4,5-trihidroksi asam benzoat, 4hidroksi 3-metoksi asam benzoat, dan 4hidroksi-3,5-dimetoksi asam benzoat bersifat sebagai antioksidan (Lelono \& Tachibana, 2013).

Saponin bertanggungjawab untuk mempertahankan konsentrasi $\mathrm{Ca}^{2+}$ intraseluler dan homeostasis $\mathrm{Ca}^{2+}$ (Mythili, Parameswari, \& Dayana, 2012). Saponin dapat merangsang sekresi insulin pada sel beta pankreas. Mekanismenya sama seperti obat hipoglikemik oral golongan sulfonilurea, dengan menghambat channel $K$-ATPase, sehingga aliran kalium keluar sel terganggu. Akibatnya terjadi depolarisasi membran sel beta pankreas, sehingga channel $\mathrm{Ca}^{2+}$-ATPase terbuka dan ion kalsium masuk ke sitoplasma. Keberadaan ion kalsium tersebut mengaktifkan enzim kalmodium dalam sel sehingga terjadi eksositosis insulin dari vesikel untuk disekresikan keluar sel (Murray, Granner, Mayes, \& Rodwel, 2003).

Terpenoid seperti triterpenoid dapat meningkatkan penyerapan glukosa dengan bertindak meniru kerja insulin dan sebagai insulin sensitizer. Triterpenoid yang dapat berperan sebagai insulin (insulinotropik) mampu berikatan dengan reseptor insulin (Lee \& Thuong, 2010). Triterpenoid juga mampu menghambat produksi TNF- $\alpha$ (Tumor Necrosis Factor) di jaringan pankreas. TNF- $\alpha$ dihasilkan oleh aktivitas ROS (Gwozdziewiczova, Linchnovska, Ben, Chlup, \& Hrebicek, 2005). Dengan dihambatnya produksi TNF- $\alpha$, maka efek kerusakan serta menurunnya sensitivitas insulin lebih rendah.

Alkaloid cincin imidazol menstimulasi sekresi insulin, menurunkan kadar glukosa darah dan memperkuat toleransi terhadap glukosa (Patel, Kumar, Laloo, \& Hemalatha, 2012).Tanin dapat menurunkan kadar glukosa darah dengan cara menangkap radikal bebas dan mengurangi peningkatan stres oksidatif pada penderita diabetes sehingga mampu mengontrol kadar glukosa darah (Widowati, 2008).

Penggunaan bersama glibenklamid dan ekstrak daun salam secara oral terbukti dapat memperbesar penurunan kadar glukosa darah. Untuk itu, pengkombinasian glibenklamid dengan ekstrak daun salam dapat dilakukan oleh pasien diabetes untuk memperbesar penurunan kadar glukosa darah, tetapi tetap diperlukan pengawasan dalam penggunaannya terutama jika digunakan lebih dari 14 hari.

\section{DAFTAR PUSTAKA}

Akhtar, M. S., Athar, M. A., \& Yaquib, M. (1981). Effect of Momordica charantia on Blood Glucose Level of Normal and Alloxan -Diabetic Rabbits. Planta Medica.

Alarcon-Aguilara, F. J., Roman-Ramos, R., Perez-Gutierrez, S., AguilarContreras, A., Contreras-Weber, C. C., \& Flores-Saenz, J. L. (1998). Study of the Anti-Hyperglycemic Effect of Plants Used as Antidiabetics. Ethnopharmacology.

Anonim. (1993). Penapisan Farmakologi, Pengujian Fitokimia dan Pengujian Klinik. Jakarta : Yayasan Pengembangan Obat Bahan Alam Phyto Medica.

Anonim. (2013). Internasional Diabetes Federation 2013. 
Brahmachari, G. (2011). Bioflavonoids with Promising Anti-Diabetic Potentials: A Critical Survey: Opportunity, Challenge, and Scope of Natural Products. Medicines Chemistry.

Carolina, R. (2007). Pengaruh Ekstrak Etanol Daun Salam (Polyanthi Folium) Terhadap Kadar Glukosa Darah Mencit Jantan Galur BALB/C Yang Diinduksi Aloksan. Universitas Surabaya, Surabaya.

Gwozdziewiczova, S., Linchnovska, R., Ben, R. Y., Chlup, R., \& Hrebicek, J. (2005). TNF-alpha in the Development of Insulin Resistance and Other Disorders in Metabolic Syndrome. Biomed Pap Med Fac Uni Palacky Olmouc Czech Repub.

Harborne, J.B., (1987). Metode Fitokimia Penuntun Cara Modern Menganalisa Tumbuhan. Bandung: Penerbit ITB.

Lee, M. S., \& Thuong, P. T. (2010). Stimulation of Glucose Uptake by Triterpenoids From Weigela Subsessilis. Phytotherapy research.

Lelono, R. A. A., \& Tachibana, S. (2013). Preliminary Studies of Indonesian Eugenia polyantha Leaf Extracts as Inhibitors of Key Enzymes for Type 2 Diabetes. J. Med. Sci.

Lenzen, S., \& Panten, U. (1988). Alloxan: History and Mecanism of Action. Diabetologia.

Liem, S. (2015). Uji Aktivitas Antidiabetes Kombinasi Glibenklamid dan Ekstrak Daun Salam (Syzygium polyanthum Wight.) Terhadap Mencit (Mus musculus) yang Diinduksi Aloksan. Universitas Tadulako, Palu.

Lugasi, A., Hovari, J., Sagi, K. V., \& Biro, L. (2003). The Role of Antioxidant Phytonutrients In The Prevention of Disease. Acta Biologica Szegediensis, 47, 119-125.

Malole, M. B. M., \& Pramono, C. S. U. (1989). Penggunaan Hewan-Hewan Percobaan dalam Laboratorium. Bogor: Departemen Pendidikan dan
Kebudayaan Direktorat Jendral Pendidikan Tinggi Antar Universitas, Bioteknologi, IPB.

Murray, R. K., Granner, D. K., Mayes, P. A., \& Rodwel, V. W. (2003). Biokimia Harper (Vol. 25). Jakarta: Penerbit Buku Kedokteran EGC.

Mythili, Parameswari, C., \& Dayana, J. (2012). Phytochemical analysis of the Bark Extract of Terminalia Arjuna and its cardioprotective Effect. 2nd National Level Students Conference on Nascent Technologies in Biomedical.

Patel, D., Kumar, R., Laloo, D., \& Hemalatha, S. (2012). Natural Medicines From Plant Source Used For Therapy of Diabetes Mellitus: An Overview of Its Pharmacological Aspects. Asian Pacific Journal of Tropical Disease.

Shahidi, F., \& Wanasundara. (1992). Phenolic Antioxidants. Crit Rev Food Sci Nutr.

Studiawan, H., \& Santosa, M. H. (2005). Uji Aktivitas Penurun Kadar Glukosa Darah Ekstrak Daun Syzygium polyanthum pada Mencit yang Diinduksi Aloksan. Medika Kedokteran Hewan.

Widowati, W. (2008). Potensi Antioksidan sebagai Antidiabetes. JKM. 